\title{
CLAY MINERALS IN THE SEDIMENTS OF LAKE BAIKAL: A USEFUL CLIMATE PROXY
}

\author{
RICHARD YURETICH ${ }^{1}$, MARTIN MELLES ${ }^{2}$, BRENN SARATA ${ }^{1}$, AND HANNES GROBE ${ }^{3}$ \\ ' Department of Geosciences, University' of Massachusetts, Box 35820, Amherst, Massachusetts 01003-5820 U.S.A. \\ e-mail: yuretich@geo.umass.edu \\ ${ }^{2}$ Alfred-Wegener-Institut für Polar-und Meeresforschung, Telegrafenberg A43, 14473 Potsdam, Germany \\ ${ }^{3}$ Alfred-Wegener-Institut fir Polar- und Meeresforschung, Columbusstraße, 27515 Bremerhaven, Germany
}

\begin{abstract}
Lake Baikal, in south-central Siberia, has been the focus of an international effort (the Baikal Drilling Project; BDP) to obtain continuous long cores (upwards of $100 \mathrm{~m}$ ) from this unique rift-valley lake and to interpret the paleoclimatic history from various proxy data. As part of this effort, the clay minerals were examined by two research teams. A consistent clay-mineral assemblage, containing illite, interstratified illite-smectite, chlorite, and kaolinite as the major minerals, characterizes much of the modern sediments. The relative abundance of these minerals changes with depth in both short piston cores from various parts of the lake and in 100-m-long cores taken from the distal toe of the Selenga Delta (BDP-93). Independent analyses of the abundance changes and correlation with other data from the cores show that the clays are responding to two influences: (1) climatic fluctuations, particularly in the upper $40 \mathrm{~m}$ of the sedimentary record, which show the relative amount of illite-smectite (and sometimes kaolinite) increasing during warmer climate episodes, and (2) source-area changes, which are most evident below $40 \mathrm{~m}$ in the BDP-93 cores and mark a shift from an eastern (Buguldeika River) to a western (Selenga River) source. The clay-mineral-based climate fluctuations are correlative with the marine oxygen-isotope record through stage 7 , and provide a relatively simple and cost-effective tool for gaining insight into the paleoclimate of this interior continental site.
\end{abstract}

\section{INTRODUCTION}

Lake Baikal, in south-central Siberia, is often described in superlatives: the world's largest and deepest lake; the largest single accumulation of the Earth's fresh-water supply; the northernmost rift-valley lake in the world (Kozhov 1963). In common with other rift valleys, it is also a place where lacustrine and perilacustrine environments have persisted for millions of years. Exposures of sedimentary rocks in several locations near the lake indicate that a lake existed as far back as the Oligocene, perhaps as long ago as 35 million years (Mats 1993). Studies in the rift-valley lakes of East Africa have verified that rift basins are uniquely positioned to record paleoclimatic fluctuations in their sedimentary successions (Johnson 1996; Johnson and N'ganga 1990; Stoffers and Hecky 1978).

The global distribution of clay minerals reveals a latitudinal zonation that strongly reflects the pedogenic and climatic zonation (Biscaye 1965; Griffin et al. 1968; Windom 1976; Chamley 1989). In tropical to subtropical environments, both lacustrine and marine clay-mineral assemblages have often been a useful guide to paleoclimatic settings, because hydrolysis of rock-forming silicates in tropical conditions can change rapidly in response to climatic phenomena (Stoffers and Hecky 1978; Kalindekafe et al. 1996; Gingele 1996). Lakes are especially sensitive, because they have repeatedly formed closed basins during more arid times, increasing the alkalinity and salinity of the water mass and inducing diagenetic alteration of the clays (Stoffers and Hecky 1978).

In cold temperate to polar regions, the chemical weathering reactions producing clay minerals have generally been viewed as being too insensitive (kinetically slow) to provide much assistance in interpreting climatic change. Under these conditions, clay minerals have been regarded primarily as source-area indicators (Windom 1976; Chamley 1989). In the Antarctic Ocean, for example, direct paleoclimatic information from clay-mineral asisemblages can be derived from sediments older than Oligocene, prior to the Antarctic glaciation (Ehrmann et al. 1992). In Neogene and Quaternary sediments, in contrast, temporal and spatial variations in clay minerals were traced back to different source areas and transport processes, the latter leading to indirect paleoclimatic conclusions (Ehrmann et al. 1992; Melles et al. 1995b).

Lake Baikal provides a unique opportunity to test the utility of clay mineralogy for paleoclimatic interpretation in a nonmarine environment at high latitude. The lake water is fresh (Kenison Falkner et al. 1991), and consequently the detrital minerals should not have undergone significant postdepositional alteration. Clay minerals, in particular, would therefore be more likely to preserve the conditions of hydrolysis that generated them in the soil profile.

The lake lies in a region critical for understanding global climate change during the Cenozoic. Much of the available information about Quaternary climatic episodes comes from the oceanic record, and there is a paucity of data about the Asian mainland. The most reliable record comes from study of the loess stratigraphy of China and Tibet, from which a climatic stratigraphy has been assembled (Kukla et al. 1988; Zhao 1992). There is a close correlation between the magnetic susceptibility of the loess and the marine oxygen-isotope records back at least $120 \mathrm{ka}$, and possibly $2.6 \mathrm{Ma}$. Although there are loess deposits in central Asia as well, correlating with the European climatic record is difficult. Of greater significance is that Lake Baikal lies in the area that would have been influenced by the uplift of the Himalayan Plateau, which has been affecting atmospheric circulation for the past $40 \mathrm{Ma}$ (Raymo and Ruddiman 1992). The sediments of Lake Baikal should be responding to the tectonic and climatic conditions produced by these events, and the clay minerals may serve as a repository of environmental changes in the surrounding watershed.

\section{The Baikal Drilling Project}

The primary goal of the Baikal Drilling Project is to obtain drill cores upward of $100 \mathrm{~m}$ long from parts of the lake where sedimentation has been relatively continuous for extended periods of time. Piston cores up to 10 $\mathrm{m}$ in length were collected during 1990-92 as part of joint expeditions between the Russian Academy of Sciences and the U.S. Geological Survey (Colman et al. 1994). Sub-bottom seismic surveys were taken in conjunction with the coring to determine the larger-scale sedimentary patterns in the lake and to locate primary targets for drill sites (Kuzmin et al. 1993; Scholz et al. 1993). The 1993 Baikal Drilling project drill site (BDP-93) is located on the distal margin of the Selenga River Delta in south-central Lake Baikal, in an area known as the Buguldeika Saddle (Fig. 1). A barge carrying the drilling rig was frozen into the ice in January 1993 and drilling continued until the ice broke up in March. Two holes were drilled side by side, and these were cored by an advanced hydraulic piston core (APC) and rotary drilling (BDP-93 Baikal Drilling Project Members 1997). These cores are being studied by an international team of Russian, American, Japanese, and German researchers in order to gain a better understanding of the magnitude of climate change on the central Siberian platform. Analyses are underway for paleomagnetic stratigraphy, radiocarbon dating, diatoms, biogenic silica, pollen content, organic geochemistry, and sedimentary mineralogy.

Two parallel cores were recovered: BDP-93-1, which has a total length 


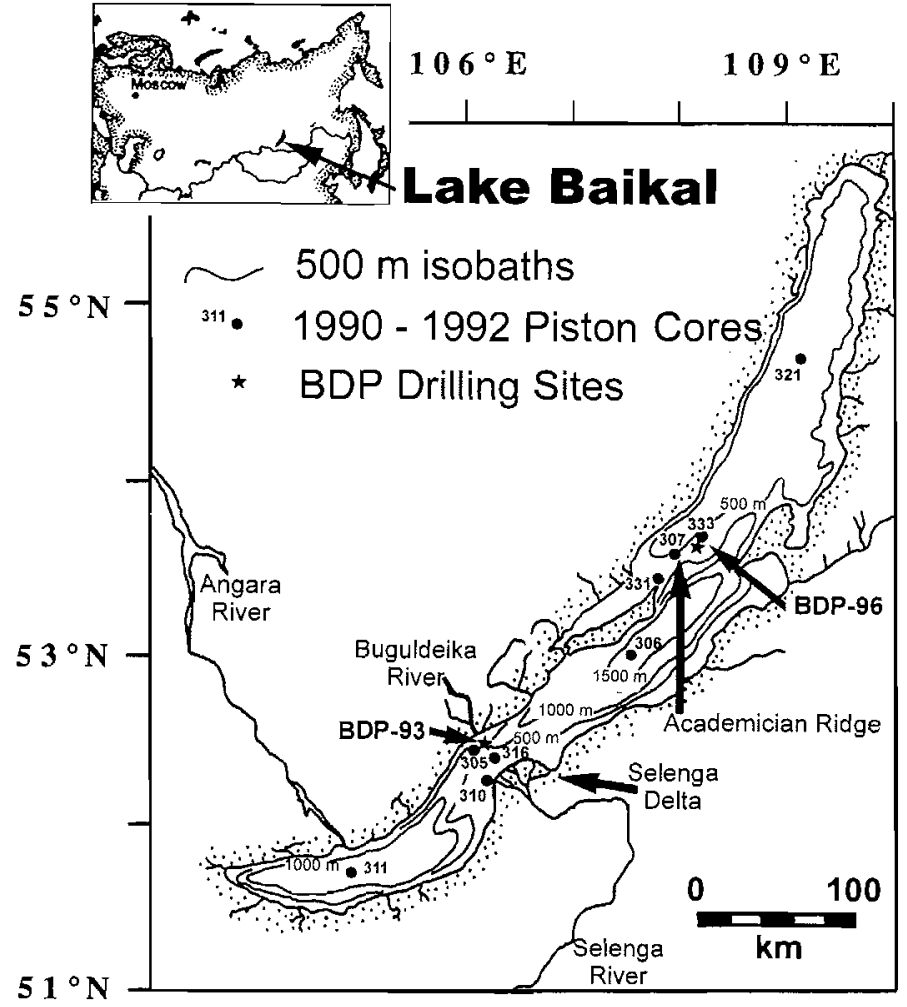

Frg. 1.-Location map of Lake Baikal showing coring and drill sites examined for clay mineralogy.

of $98 \mathrm{~m}$, and BDP-93-2, which is $102 \mathrm{~m}$ long. The cores show two distinct sedimentary divisions. The upper $35 \mathrm{~m}$ are dominated by fine-grained silts and clays containing laminae characteristic of deposition in a pelagic, lacustrine environment. The lower part of the core is generally sandier, with numerous intervals of graded bedding, indicating a delta-proximal environment with a stronger influence of fluvial and gravitational transport on sediment deposition (BDP-93 Baikal Drilling Project Members 1997).

Paleomagnetic analyses show normal polarity in almost all samples from both cores, indicating that the sediments are younger than the BrunhesMatuyama polarity reversal at $780 \mathrm{ka}$ (Hayashida and Yokoyama 1994, 1995; BDP-93 Baikal Drilling Project Members 1997). AMS radiocarbon dates of the upper part of the core yield sedimentation rates of $175 \mathrm{~mm} /$

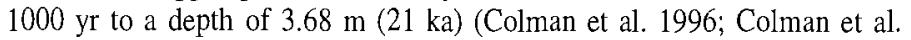
in press). Correlation of relative variation in paleomagnetic intensity within the core provide additional control points down to a depth of $39.58 \mathrm{~m} \mathrm{(264}$ ka) (John Peck, unpublished data; Colman et al. in press). Extrapolation of the average sedimentation rate during this upper interval yields ages of 334 $\mathrm{ka}$ at $50 \mathrm{~m}$ and $675 \mathrm{ka}$ at $100 \mathrm{~m}$, although the latter number is very speculative at this point. In addition, a magnetic excursion occurring between 25.5 and $27 \mathrm{~m}$ in BDP-93-2 has been tentatively identified as the "Jamaica" or "Biwa 1" event (180 ka) (Nowaczyk 1995; BDP-93 Baikal Drilling Project Members 1997). Extrapolation of this age also gives a date of about $670 \mathrm{ka}$ at the core bottom, although Nowaczyk (1995) maintains that the core bottom is just below the Brunhes-Matuyama boundary. Additional studies are in progress to refine the age models for the lower part of the core.

Initial investigations of Lake Baikal sediments show some indication of sensitivity to climate change. Carter and Colman (1994), Peck et. al. (1994) and Colman et. al. (1995) have shown that biogenic silica in the cores can serve as a useful climate proxy. Biogenic silica tends to increase in the sediments as a result of elevated diatom productivity in the lake, which, in turn, is responding to warmer water temperatures and a higher nutrient influx to the lake during runoff. Our goal is to determine whether patterns in the mineralogical composition of the sediments can also be used as a supporting tool for paleoclimatic interpretation. We have presented some preliminary data showing that the clays appear to show some climatic sensitivity (Melles et al. 1995a; Sarata and Yuretich 1995); in this paper we analyze the clay data rigorously and compare them with other results from the Baikal Drilling Project in order to unravel the tectonic and climatic history of Lake Baikal.

\section{METHODS}

Several of the piston cores collected by the U.S. Geological Survey were sampled in October 1992 for a preliminary survey of the clay minerals (Fig. 1).

Samples from each of the two cores from the 1993 Baikal Drilling Project were run for clay minerals. For the first core, BDP-93-1, subsamples for analysis spanning an interval of $3 \mathrm{~cm}$ were taken at approximately $\mathrm{l}$ $\mathrm{m}$ spacing; a total of 62 samples were available for mineralogical characterization. BDP-93-2 was sampled more intensively, with subsamples collected every 5 to $6 \mathrm{~cm}$ along the entire length of the core, for a total of 1374 samples. The U.S. and German investigators each received one-third of these samples (458) from adjacent depth intervals in the core.

Clay minerals were analyzed independently at the University of Massachusetts and the Alfred Wegener Institute. The U.S. samples were dried at $60^{\circ} \mathrm{C}$, weighed, and transferred into pre-weighed $250 \mathrm{ml}$ polyethylene centrifuge bottles. The sediment was disaggregated and dispersed ultrasonically and then wet-sieved to remove the $>63 \mu \mathrm{m}$ (sand) size fraction. The slurry containing the fine fraction was centrifuged on an IEC-UV centrifuge at $500 \mathrm{rpm}$ for 9 minutes 37 seconds to cause all grains $>2 \mu \mathrm{m}$ to settle out, according to Stokes' Law determinations. The silt fraction in the bottom of the bottle was dried and weighed for grain-size determinations. The supernatant liquid was transferred to clean bottles and centrifuged at 10,000 rpm on a Sorvall RC2-B high-speed centrifuge for at least 30 minutes to sediment all particles. After the water was removed by suction, the remaining paste was applied to petrographic slides by smearing to prepare an oriented mount and dried in ambient atmosphere. These were examined via $\mathrm{X}$-ray diffraction with $\mathrm{Cu}$ radiation using a Siemens Type $\mathrm{F}$ goniometer updated with a Databox digital processing system. Diffraction patterns were scanned from $2^{\circ}$ to $30^{\circ} 2 \theta$, with a step size of $0.05^{\circ}$ and a counting time of $1 \mathrm{~s}$. Samples were then placed in a desiccator containing ethylene glycol and solvated in the glycol-rich atmosphere at $60^{\circ} \mathrm{C}$ for up to 24 hours. Several samples were also heated in a muffle furnace at $550^{\circ} \mathrm{C}$ for 1 hour. General grain-size data were obtained from weighing the sand and silt fractions. Selected samples also had the $<0.1 \mu \mathrm{m}$ size fraction by centrifuging at $10,000 \mathrm{rpm}$ for 9 minutes 37 seconds in order to determine the characteristics of the finest material.

The samples of BDP-93-2 analyzed at the Alfred Wegener Institute were taken from depths in the core adjacent to those examined at the University of Massachusetts. Samples were oxidized and disaggregated with 3 to 5\% $\mathrm{H}_{2} \mathrm{O}_{2}$, then sieved through $63 \mu \mathrm{m}$ mesh. The $<2 \mu \mathrm{m}$ fraction was subsequently isolated by the Atterberg method, with settling times based on Stokes' Law. The clays were saturated with $\mathrm{MgCl}_{2}$, washed twice by centrifugation with distilled water, dried at $60^{\circ} \mathrm{C}$, and ground by hand in an agate mortar. From every sample $40 \mathrm{mg}$ was dispersed ultrasonically and mixed with $1 \mathrm{ml}$ of a $1 \% \mathrm{MoS}_{2}$ suspension. The entire slurry was filtered through a membrane of $0.15 \mu \mathrm{m}$, and the resulting filter cakes were solvated with ethylene glycol at $60^{\circ} \mathrm{C}$ for about 24 hours. X-ray diffraction was accomplished using Co radiation and a Phillips PW 1820 automated diffractometer with a step of $0.02^{\circ}$ and a counting time of $1 \mathrm{~s}$ (Melles et al. 1995a).

The clay minerals were identified primarily by basal $(001)$ diffraction lines on glycolated specimens: smectite, $17 \AA$; chlorite, $14.2,7$, and 3.54 

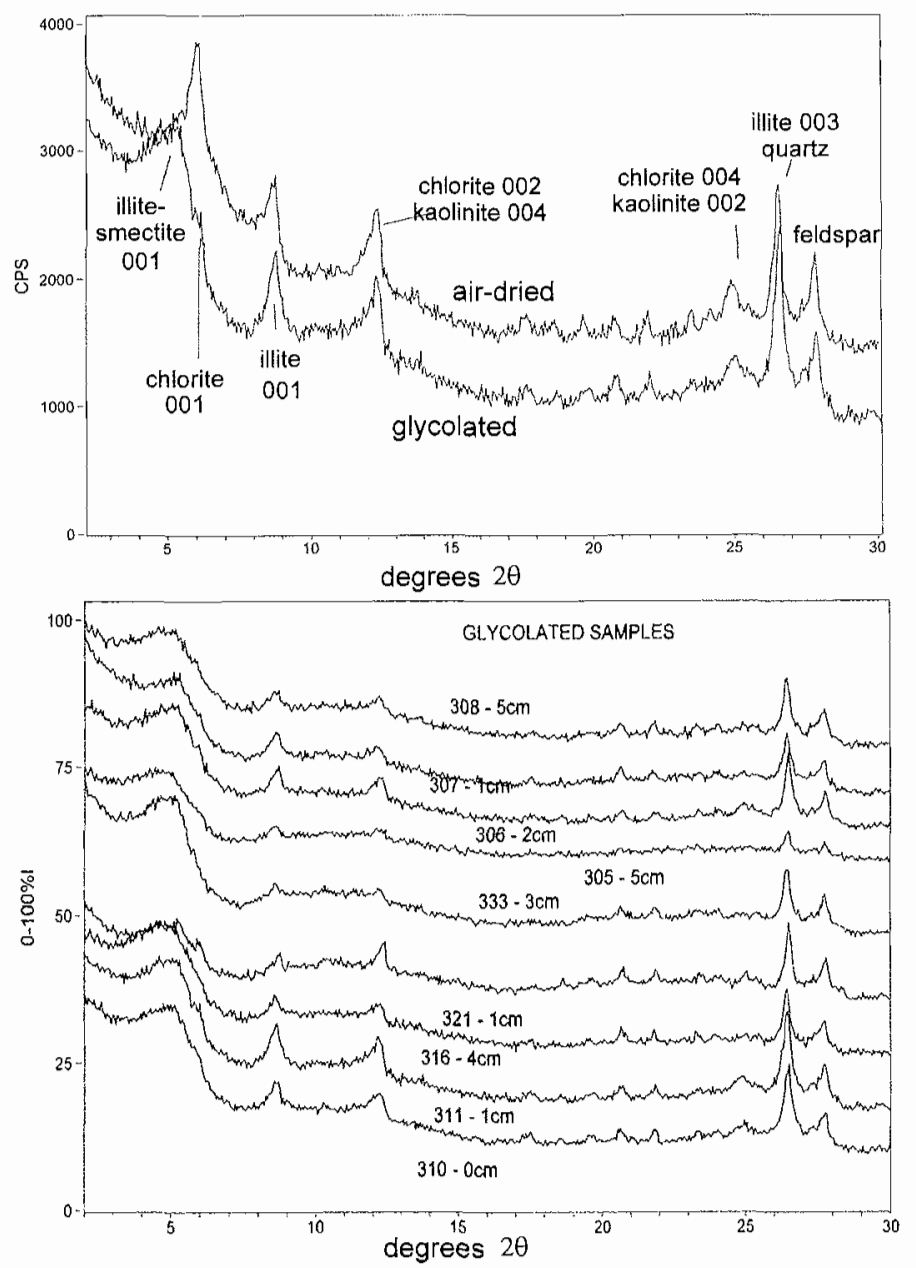

FIG. 2.-X-ray diffractograms of clay minerals in Lake Baikal. Top: Indexed representative diffractogram of air-dried and glycolated samples from piston core 311 (depth 1-3 cm). Bottom: Comparison of X-ray diffractograms from uppermost samples of all piston cores showing the relative geographic consistency of the claymineral assemblage. Semiquantitative abundance is given in Table 1.

$\AA$; illite, $10 \AA$; and kaolinite, 7 and $3.58 \AA$. Semiquantitative estimates of mineral abundance were based on integrated peak areas determined either via the computer programs Jade ${ }^{\circledR}$ (version 2.0) at the University of Massachusetts or "MacDiff" (Petschik et al. 1996) at the Alfred Wegener Institute. The relative percentages of the clay minerals were determined using the empirical weighting factors of Biscaye (1964, 1965). Although this method does not give a truly quantitative measure of different claymineral types, it provides a useful guide to relative changes within a sequence (Menking 1997). The samples processed by the Alfred Wegener Institute were further quantified by comparisons to the internal $\mathrm{MoS}_{2}$ standard (Ehrmann et al. 1992; Melles et al. 1995a).

\section{RESULTS}

Grain-size analyses from some of the earlier piston cores indicate that the sediments contain anywhere from $10 \%$ to $65 \%$ clay (Colman et al. 1994). The average grain size for the various cores show some differences, although there are no readily apparent geographic trends in the extant data. The grain-size analyses of the BDP-93-2 samples yielded somewhat different results at the two laboratories. Samples processed by the University of Massachusetts averaged $21( \pm 9) \%$ clay $(<2 \mu \mathrm{m})$ for the BDP-93-2 core, with a range between $2 \%$ and $54 \%$, on the basis of 175 samples. The
TABLE 1.-Relative clay-mineral abundance in uppermost samples of piston cores

\begin{tabular}{lccccc}
\hline \hline Core & $\begin{array}{c}\text { Sample } \\
\text { Depth }(\mathrm{cm})\end{array}$ & $\begin{array}{c}\text { \% lllite- } \\
\text { Smectite }\end{array}$ & \% llite & \% Chlorite & $\begin{array}{c}c \\
\text { Kaolinite }\end{array}$ \\
\hline 305 & $5-8$ & 86 & 10 & 3 & 1 \\
306 & $2-4$ & 61 & 29 & 8 & 2 \\
307 & $1-3$ & 33 & 54 & 13 & 0 \\
308 & $5-7$ & 76 & 10 & 7 & 7 \\
310 & $0-2$ & 50 & 33 & 9 & 9 \\
311 & $1-3$ & 38 & 42 & 14 & 6 \\
316 & $8-10$ & 74 & 20 & 4 & 1 \\
321 & $1-3$ & 72 & 13 & 11 & 4 \\
333 & $3-5$ & 72 & 22 & 3 & 2 \\
Average (std. dev.) & & $65( \pm 17)$ & $24( \pm 15)$ & $11( \pm 4)$ & $3( \pm 3)$ \\
$-*$ Core locations are shown & & & & &
\end{tabular}

Alfred Wegener Institute determined an average of 39 ( \pm 10$) \%$ clay, with a range from $2 \%$ to $58 \%$ in BDP-93-2 using all 458 samples. The difference in the averages is presumably a function of the different numbers of samples and procedures used in the analyses. Moreover, the two laboratories did not study samples from exactly the same levels in the core. The overlap in standard deviation together with the similar range in the clay-size data give assurance that the results are comparable.

The principal clay minerals in all the samples recovered from Lake Baikal are smectite, illite, chlorite, and kaolinite (Fig. 2). The broad peak around $17 \AA$ on the glycol-solvated X-ray diffractograms together with the high background in the low-angle shoulder of this peak indicates that this phase is actually an interstratified illite-smectite (1-S). This appears to be a random, disordered interstratification, which is common in modern soil clays. The absence of identifiable secondary peaks $(002,003)$ makes it difficult to establish the exact illite content of the I-S. However, comparisons with experimental and theoretical diffraction data (Eberl et al. 1993; ReynoIds 1980) indicate that the expandable phase is $\sim 60 \%$.

\section{Geographic Variability and Reproducibility of Data}

There is some variability in X-ray intensity of the different minerals from different samples around the lake, but the general similarities of the modern sediments are quite clear (Fig. 2; Table 1). Samples from the uppermost 5 $\mathrm{cm}$ of the piston cores contain illite-smectite as the most abundant, followed by illite, chlorite, and generally small amounts of kaolinite. There is some variability in the modern sediments related to the location within the lake basin, presumably reflecting differences in the depositional processes at the various sites. The Selenga Delta region is closest to drill site BDP-93, and cores 310,316 , and 305 form a transect from proximal to distal locations on the delta. The I-S content of the sediments increases along this transect, as is common in deltaic environments (Gibbs 1977). The smectite is dominantly a dioctahedral variety, which confirms earlier analyses done on piston cores (Deike et al. 1993). The low intensity of the odd 001 diffraction lines suggests that the chlorite is an iron-rich variety, but this needs to be confirmed by more detailed analyses.

The US team compared the relative clay-mineral abundance in the 60 samples from BDP-93-1 with samples from approximately the same depth in core BDP-93-2. Both cores show similar changes in the relative clay mineral abundance with depth, although the magnitude of the changes is not always identical (Fig. 3). Because the samples do not come from exactly the same depth in the two cores, the data are not amenable to a direct statistical analysis. However, when the data are smoothed (locally weighted least-squares regression, coefficient $=0.3$ ) and then regressed upon each other, they yield an $R^{2}=0.79$. Much of the discrepancy comes from the lower part of the 93-1 core because of problems in correctly identifying the depth at the time of core collection. The agreement between the two data sets, analyzed at two different times, indicates that the general trends in clay-mineral abundance are reproducible.

The relative abundances of the clay minerals in BDP-93-2 have different 


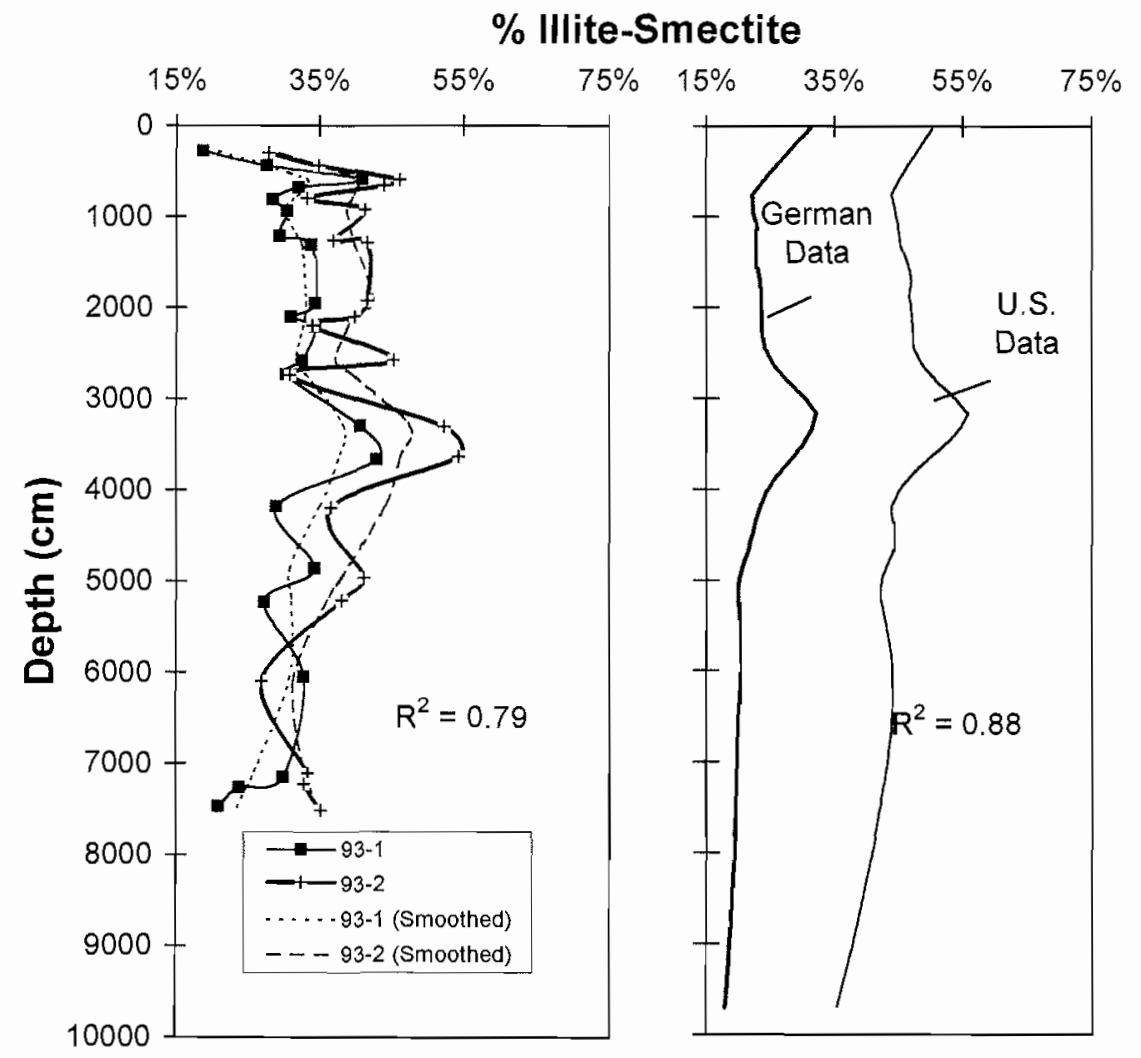

FIG. 3.-Trends in relative abundance of illitesmectite in parallel cores. Left: Comparison of actual and smoothed abundances in BDP-93-1 and BDP-93-2 from U.S. data. Right:

Comparison of trends identified in U.S. and German data from BDP-93-2. numerical values in the German and U.S. data sets, owing to different preparation methods and analytical conditions, but the trends down core are very similar. Smoothed curves of the illite-smectite abundance (locally weighted least-squares regression, coefficient $=0.3$ ) indicate the high degree of concordance $\left(R^{2}=0.88\right)$ between the analyses conducted at the two different laboratories (Fig. 3). Such consistency reinforces the utility of the X-ray diffraction data for eliciting actual changes in clay-mineral abundance.

\section{Details of Down-Core Variations in Clay-Mineral Abundance}

In general, the I-S trends visible in the smoothed curves divide the cores into three broad segments. In the upper $8 \mathrm{~m}$, the I-S declines with depth by $8-10 \%$. This is followed by an increase of $2-3 \%$ to a depth of -25 $\mathrm{m}$, and an additional increase of $6-8 \%$ by a depth of $32 \mathrm{~m}$. The third segment is the decline in I-S by $12-15 \%$ from this depth until the bottom of the core. Superimposed upon these broad trends are higher-frequency variations most likely caused by more subtle changes in environmental conditions. Again, illite-smectite serves as the representative marker because of its abundance and sensitivity to environmental change. However, parallel fluctuations occur in the other clay minerals, most notably illite (Fig. 4).

In order to more effectively compare the details of the changes in the illite-smectite, a regression equation was calculated between the U.S. and German results for samples of comparable depth (within $7 \mathrm{~cm}$ ). The German data were then transformed according to this equation $y=0.8017 x$ +26.99 ) to adjust the relative abundance of $I-S$ to a comparable level (Fig. 5). Both data sets show a downward decrease of $30 \%$ in I-S in the upper $2.5 \mathrm{~m}$ of the BDP-93-2 cores (Zone A). I-S abundance remains nearly constant at $\sim 40 \%$ until ca. $5 \mathrm{~m}$ (Zone B) but again increases to nearly $60 \%$ at $9 \mathrm{~m}$ down core (Zone C). Following a decrease to as little as $20 \% \mathrm{I}-\mathrm{S}$ that culminates at around $10 \mathrm{~m}$ depth (Zone D), the I-S abundance rises and remains relatively constant for a long interval (Zone E; until ca. $17 \mathrm{~m}$ ). This is underlain by a short section from $17 \mathrm{~m}$ to $19 \mathrm{~m}$, Zone F, where I-S rises to nearly $70 \%$. Zone $\mathrm{G}$, from 19 to $29 \mathrm{~m}$, is characterized by a relatively constant amount of I-S near $50 \%$. In Zone H, from 29 to $36 \mathrm{~m}$ depth, occur the consistently highest values of $\mathrm{I}-\mathrm{S}$ in the entire core, in excess of $75 \%$. This level marks the transition from I-S increase to decrease observable in the smoothed data (Fig. 3).

The top of Zone I coincides with the lithological boundary between the upper hemipelagic sediments and the underlying deltaic deposits in the core; here the I-S hovers around 50\%. The American data contain fewer points in this part of the core than the German data, yet the parallelism of the two curves is still excellent. In Zone J, which starts at $40 \mathrm{~m}, \mathrm{I}-\mathrm{S}$ oscillates around $40 \%$ until $56 \mathrm{~m}$. A sharp decrease to $30 \%$ I-S marks the top of Zone $\mathrm{K}$, which continues to $66 \mathrm{~m}$. At this depth, the I-S rises rapidly to approximately $60 \%$ and then gradually declines to $40 \%$ at a depth of 80 $\mathrm{m}$ (Zone L). Zone M, which ends around $87 \mathrm{~m}$, is a segment that contains a low amount of I-S, near 20\%. A short interval with I-S up to $60 \%$ comprises Zone $\mathrm{N}(87-91 \mathrm{~m})$, and then there is a generally persistent decline until the bottom of the core is reached (Zone 0 ). Illite patterns are generally mirror images of the smectite, and the agreement between the German and American sets is very close (Fig. 4).

The variations in the German data were also examined using internal $\mathrm{MoS}_{2}$ standards. These mineral/standard ratios are independent of the accumulation of other minerals and thus may be more reliable than relative percentages of the bulk clay minerals for determining true abundance and interpreting environmental changes. In other words, this avoids the "closure problem" of forcing all clay minerals to total $100 \%$, which can skew the results for some phases. Nevertheless, when a regression between the relative abundance based upon peak-area measurements and the ratios to the $\mathrm{MoS}_{2}$ standard are run, I-S has a very high correlation coefficient $\left(r^{2}\right.$ $=0.82$ ), indicating that the relative abundance is a very good indicator of actual changes. The correlation coefficients for kaolinite $\left(r^{2}=0.76\right)$ and illite $\left(r^{2}=0.61\right)$ are also high; only chlorite has a low correlation $\left(r^{2}=\right.$ 


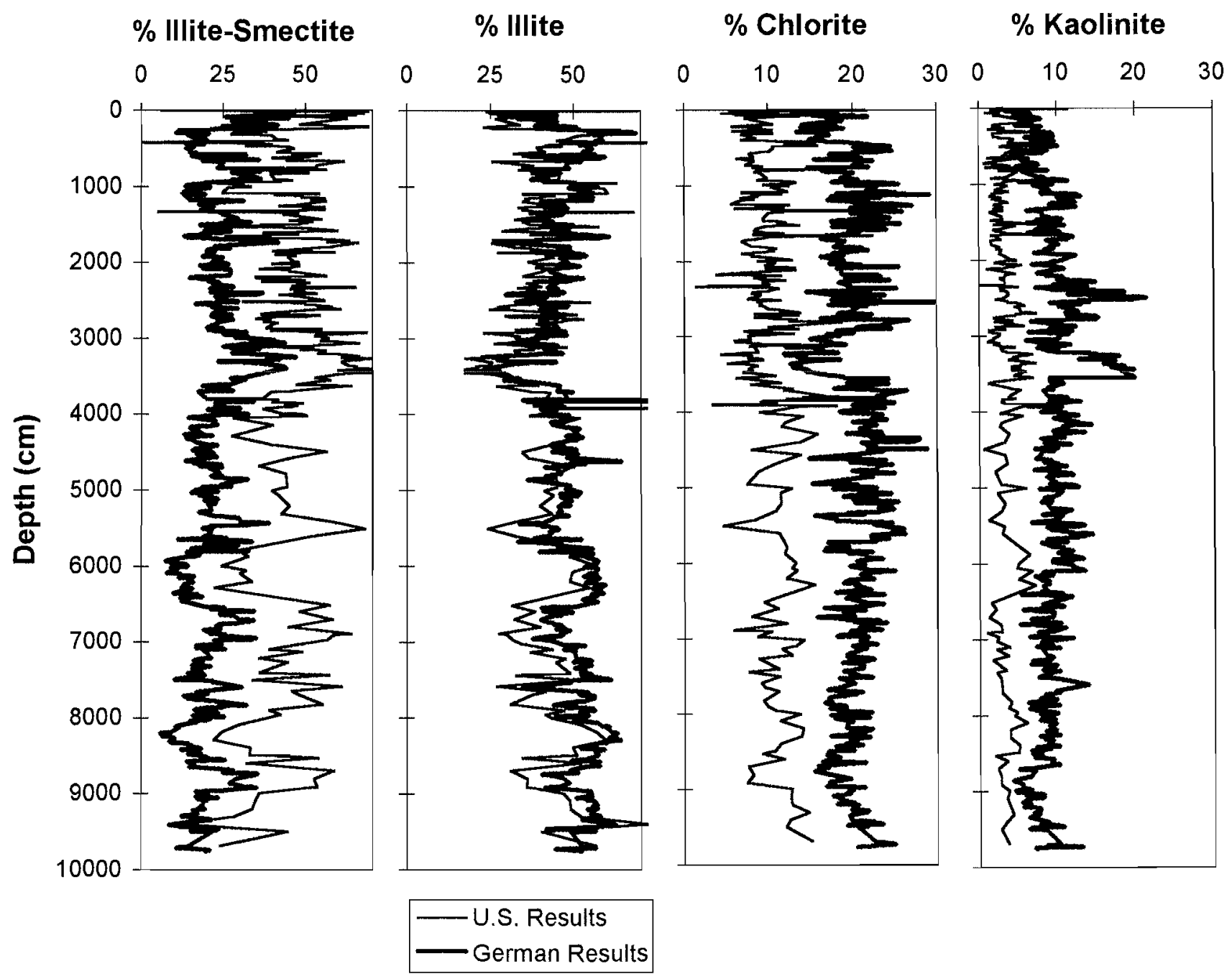

Fig. 4.-Relative abundance of all clay minerals in BDP-93-2 from U.S. and German data sets (actual data).

0.25 ) that would exclude the use of relative abundance to interpret actual mineral fluctuations.

The $\mathrm{MoS}_{2}$ standard additionally enables the quantification of other minerals in the clay fraction, such as quartz and feldspar, which correlate very well in core BDP-93-2 (Fig. 6). Mineral variations in the German data set are most visible in weighted smooth curves (locally weighted least-squares regression, coefficient $=0.05$ ), fitted to the mineral/standard ratios. The curves clearly show the interdependence of mineral contents and allow the classification of three principal clay facies having distinct mineral compositions. Clay facies $l$ is characterized by high contents of illite-smectite, quartz, and feldspar, and low contents of illite, chlorite, and kaolinite. This facies is recognized in 11 sediment horizons in core BDP-93-2, including the near-surface sediments. This alternates with clay facies 2 throughout most of the core, which shows an opposite composition: high contents of illite, chlorite, and kaolinite, and low contents of I-S, quartz, and feldspar. Clay facies 3 occurs in one horizon, exclusively, between 33 and $37 \mathrm{~m}$ depth. This facies is characterized by an elevated abundance of I-S and kaolinite and low contents of illite, chlorite, quartz, and feldspar. These clay facies are coincident with many of the I-S zones identified previously (and independently). Clay facies 1 comprises zones A, C, E, I, and N. Zones $\mathrm{B}, \mathrm{D}, \mathrm{F}, \mathrm{K}$, and $\mathrm{O}$ are all clay facies 2 . Zone $\mathrm{H}$ is clay facies 3 . Zones $\mathrm{G}$, $\mathrm{J}$, and $\mathrm{L}$, which are characterized by long intervals of relatively constant smectite, contain alternating layers of facies 1 and 2 when the other minerals are considered.

DISCUSSION

The different analytical techniques and comparative analyses demonstrate that relative changes in clay mineral abundance obtained via X-ray diffraction, especially illite-smectite, provide a true measure of the actual mineralogical changes in the Baikal drill cores. These, in turn, may result from fluctuations in climate in the Lake Baikal region. Weathering conditions in the watershed are different during wet or warm versus cold or dry episodes, such that the proportion of clay minerals delivered to the basin is altered if there is sufficient time for a quasi-equilibrium to be established. Although the processes of clay-mineral formation in soils are complex, the large size of the Lake Baikal basin and the dominance of sedimentation by a single river, the Selenga, homogenizes the mineralogy eroded from the watershed. This is evident from the relatively uniform clay-mineral distribution present in piston cores from various parts of the lake. Moreover changes in other climatically sensitive properties of the sediments support the interpretation based on clay mineralogy. Carter and Colman (1994), Peck et. al. (1994), and Colman et. al. (1995) have shown that biogenic silica increases in the sediments during episodes of warm climate. Our 


\section{$\%$ Illite-Smectite}
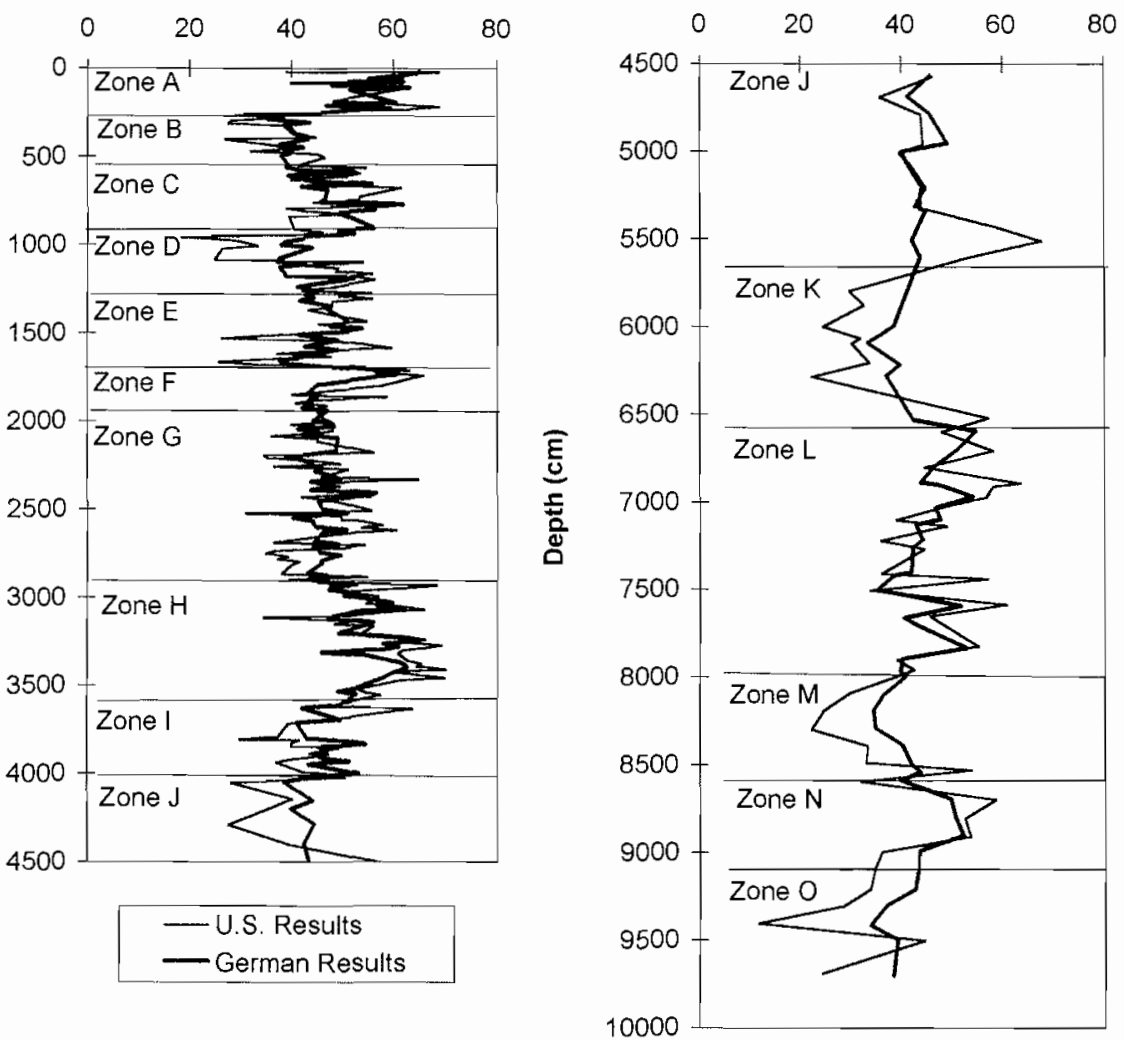

Fig. 5.-Detailed analysis of the relative trends in illite-smectite abundance and the I-S zonation. The German data have been multiplied by the regression equation relating the two data sets in order to provide comparable abundance estimates.

study confirms a correlation between the I-S abundance and the biogenic silica in the upper part of core BDP-93-2 (Fig 7). Warmer climatic conditions favor elevated hydrolysis of aluminosilicates in the Baikal watershed, and produce disordered illite-smectite in the soils at the expense of illite. On this basis, I-S zones A, C, and E should represent warm episodes, as do the upper parts of zones $\mathrm{F}$ and $\mathrm{H}$ (both clay facies 1 ). The interbedded zones of clay facies 2 correspond to much lower amounts of biogenic silica in the sediments. Curiously, the bulk of zone $\mathrm{H}$, corresponding to clay facies 3, which has the most kaolinite and I-S in it, does not have a counterpart in the data on biogenic silica, and there is essentially no silica in the underlying sediments. This can be interpreted in two ways: (1) factors other than climate are controlling the mineralogy in this interval or (2) preexisting biogenic silica in the lower half of the core has dissolved postdepositionally. Lake Baikal water has very low concentrations of dissolved silica (1-2 mg/l; Votinshev 1965), so that $\mathrm{SiO}_{2}$ is normally undersaturated and can be expected to dissolve with depth in the sediments. Consequently, the clay minerals can provide a longer record of paleoclimatic changes.

The chronology is of critical importance if the mineral abundance is to have meaningful climatic significance. The AMS radiocarbon dates and magnetic properties in both piston cores and the BDP-93 sections give good results for the Late Quaternary (Colman et al. 1996; Peck et al. 1994; Peck et al. 1996; BDP-93 Baikal Drilling Project Members 1997). In addition, the excellent correlation between biogenic silica and the SPECMAP oxygen-isotope record (Colman et al. 1995) permits an extension of the chronology with reasonable confidence.

Warm climates with vigorous chemical weathering and soil formation are indicated by clay facies 1 (Fig. 6). This facies is characterized by relative increases in the amount of quartz and feldspar and a similar change in I-S. Using the best available age model and the correlation with the SPECMAP record, this clay facies represented by smectite zones $\mathrm{A}, \mathrm{C}$, and E corresponds to isotope stages 1,3 , and 5, respectively (Fig. 7). Clay facies 2 , in contrast, probably represents colder climatic conditions. This facies is characterized by positive excursions in the abundance of illite and chlorite. These minerals are common in high latitudes and result principally from physical weathering and glacial scour of crystalline rocks (Biscaye 1965; Griffin et al. 1968). Even though the kaolinite content is also relatively high in this assemblage, this does not necessarily argue against a cold climate, because kaolinite is a very resistant mineral and thus could be derived from physical weathering of kaolinite-bearing sedimentary rocks and erosion of paleosols (Ehrmann et al. 1992). In this facies, zones B, D, and $G$ correspond closely to the times of colder climates (high ice volume) as deduced from the SPECMAP isotope curve.

Clay facies 3, corresponding to I-S zone H, occurs at a depth of 33-37 m. This facies marks a major "illite-smectite event", being coupled to an unusually large amount of kaolinite, which is most visible in the ratios to the $\mathrm{MoS}_{2}$ standards (Fig. 6). According to the temporal correlation, this horizon corresponds to an age range of 200-240 ka, which coincides approximately with the warm isotope stage 7 time period (Fig. 7). However, the unusual mineral assemblage indicates that other factors are at work here. There is evidently a source-area signal contained within the trend, because the sediments below this level change from hemipelagic sediments derived from the distal Selenga Delta to more proximal turbidite deposits derived from the ancestral Buguldeika River. This latter river had its source in Proterozoic sandstone, siltstone, and conglomerate (Ushakovskaya Suite; Khrenov 1983), which would presumably contain greater amounts of primary chlorite and mica (illite). These latter clays are more abundant in the lower part of the core. Hence, the distinct I-S high in 33-37 $\mathrm{m}$ depth in core BDP-93-2 probably marks the onset of major sediment supply from Selenga River. With this event, increased erosion of soils in the Selenga catchment area may have occurred, leading to extremely high I-S influx into Lake Baikal.

In the lower parts of the core (zones I and J), the correlation of the clay 


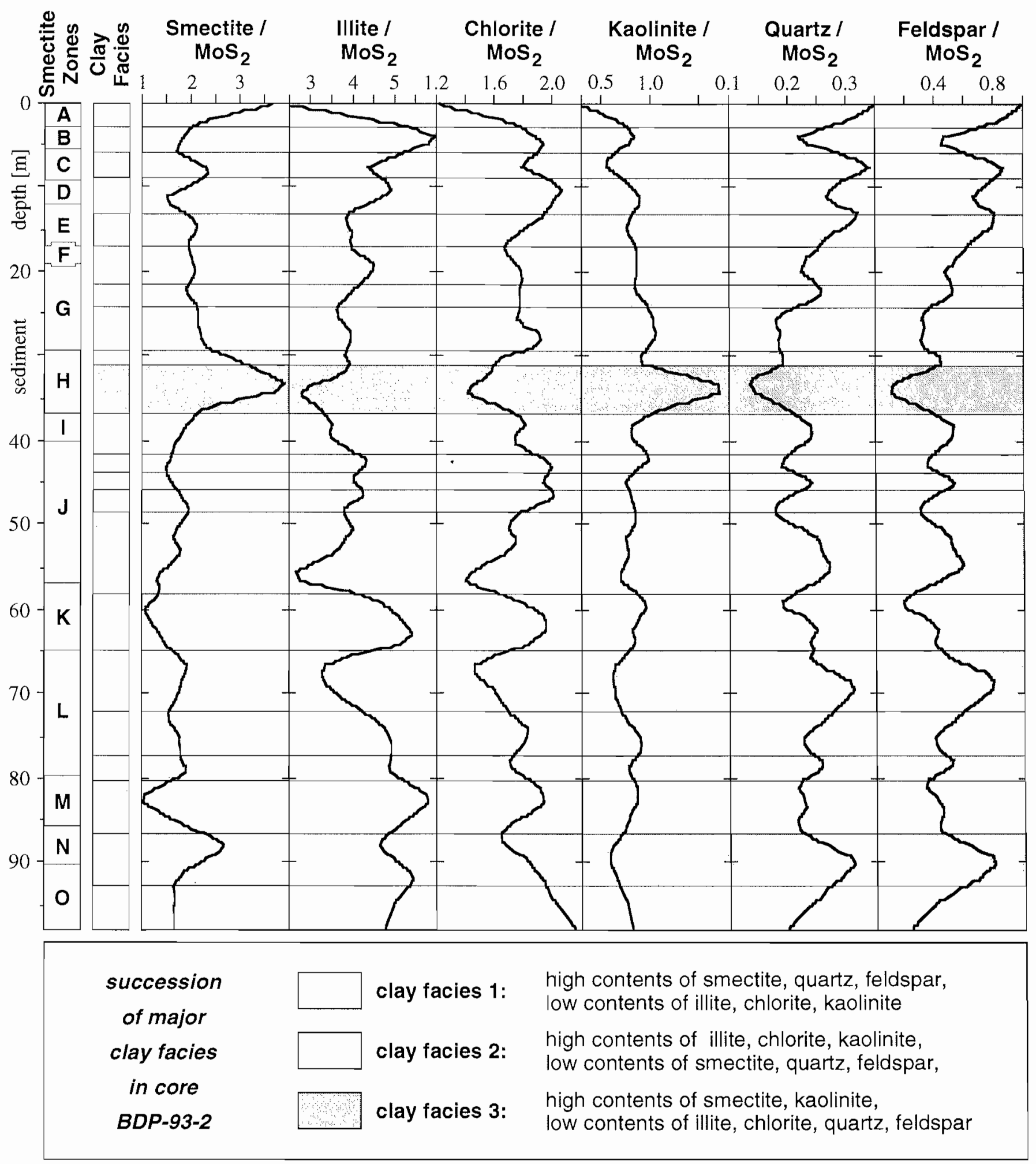

Fig. 6. - Smoothed curves of clay-mineral abundance with respect to $\mathrm{MoS}_{2}$ standards in the BDP-93-2 core (German data). I-S zones from Figure 4 are shown in lefthand column. 


\section{Relative Abundance}

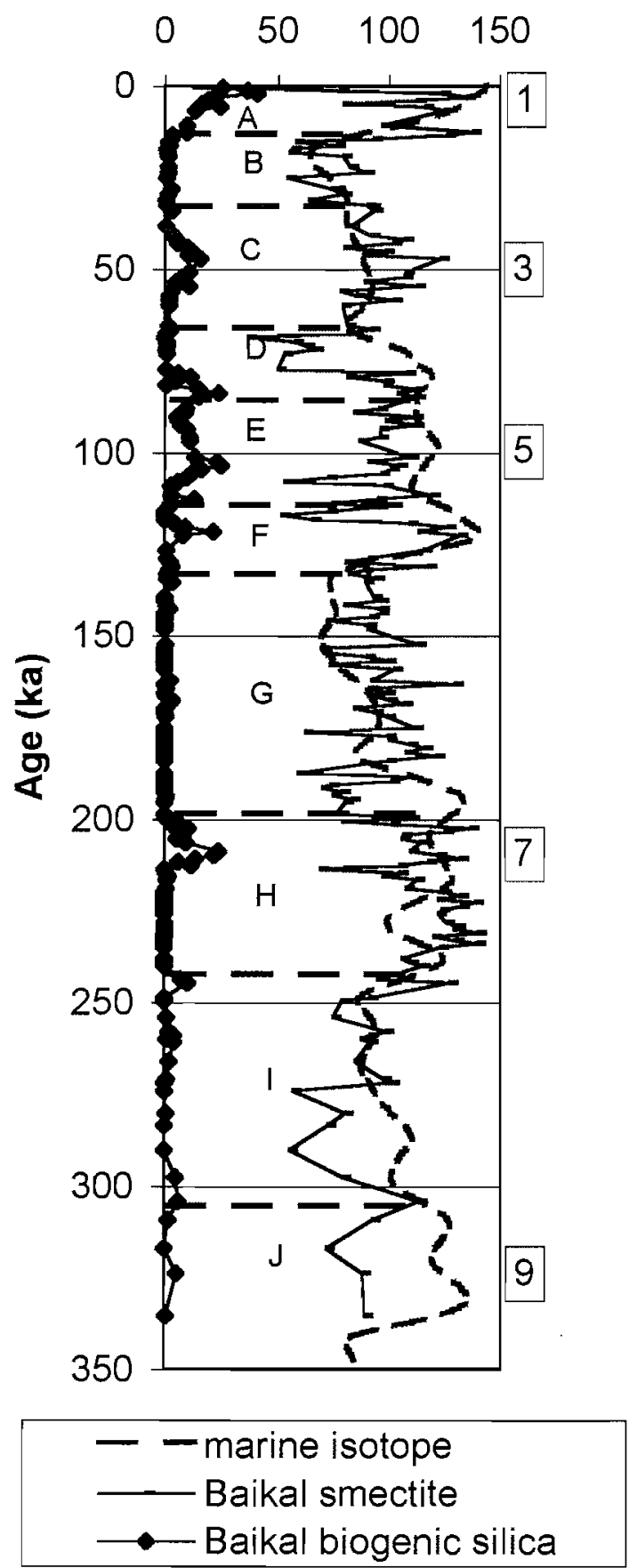

FIg. 7.-Correlation of illite-smectite content (U.S. data) and biogenic silica (Colman et al. 1996) in Lake Baikal cores with the SPECMAP oxygen-isotope curve. Letters are I-S zones (see text) and boxed numbers are isotopic interglacial episodes.

minerals with the isotope curve disappears. This can be attributed to the nature of the sedimentation, which was episodic and dominated by prodeltaic turbidites, as opposed to the largely pelagic sediments in the upper zones. Any "weathering signal" that may have resided in the suspended sediments would have been obscured during deposition. Moreover, the chronology and sedimentation rate for this part of the core is far less certain.

Menking (1997) conducted an independent test of the relationships be- tween clay minerals in lake sediments in Owens Lake, California and changes in the Quaternary paleoclimate. Using procedures similar to those we used for Lake Baikal, she determined that the clay-mineral assemblages were responding to cold and warm periods corresponding with the marine oxygen-isotope record. In particular, the trends in smectite abundance show a remarkable similarity with the I-S patterns observed in Baikal BDP-93.

Further confirmation of the relationship of clay mineralogy to climate can come from a thorough analysis of representative soil mineralogy within the Lake Baikal watershed. The distribution and composition of clay minerals in the Selenga River watershed will help establish the relationships between this component and the suspended clays entering the lake today. A drill core of approximately $200 \mathrm{~m}$ in length has recently been collected from the Academician Ridge area in the northern parts of Lake Baikal (BDP-96; Fig. 1). Although the sedimentation rate at this location is slower (40 mm/1000 yr) and the sampled record longer, up to $5 \mathrm{Ma}$ (Baikal Drilling Project BDP-96 Members 1997), a further test of the climate signal can be made by comparing contemporaneous intervals. Additional drilling in future years has been proposed in the Selenga River area; this will also help constrain the magnitude of the climatic fluctuations preserved in the clay minerals. Nevertheless, the information gathered from the BDP-93 cores confirms the utility of clay mineralogy for interpreting climatic fluctuations.

\section{CONCLUSIONS}

Lake Baikal core BDP-93 contains a ca. 600,000-year-long record of detrital clay-mineral sedimentation from which paleoclimatic conditions can be interpreted. Illite-smectite (I-S), illite, kaolinite, and chlorite are the components of the $<2 \mu \mathrm{m}$ size fraction, and the relative abundance of these minerals has a restricted geographic variability within the modern sediments of the lake. However, these clay minerals show a much larger and internally consistent variation with depth in the BDP-93 cores. Correlation of illite-smectite with abundance of biogenic silica and the SPECMAP oxygen-isotope curve indicates that most zones of high I-S occur during interglacial episodes; conversely, chlorite shows a relative increase during glacial or cold periods. These cyclical warm and cold episodes can be traced in 100-m-long cores from the Buguldeika drill site (BDP-93-1 and BDP-93-2) to depths of about $35 \mathrm{~m}$ in the core. At this level there is a maximum in I-S abundance, corresponding approximately to an interval from $250 \mathrm{ka}$ to $200 \mathrm{ka}$. Below $35 \mathrm{~m}$, clay mineral patterns indicate that the Buguldeika River, which drains the western margin of the lake, has dominated sedimentation at this location. This corroborates evidence from both the core lithology and sub-bottom seismic profiles. At this juncture it is uncertain whether the source-area shift had a climatic or tectonic cause. However, the utility of using clay minerals as an additional tool for unraveling the paleoclimatic history in a large freshwater lake has been confirmed by this study.

\section{ACKNOWLEDGMENTS}

The authors are grateful to the many people in the Baikal Drilling Project who participated in the recovery of the core and the distribution of the samples. Helpful comments on earlier versions of this manuscript were provided by John Peck, ISR reviewers Ray Ferrell and Richard Hay, and Associate Editor Robin Renaut. The U.S. study was supported by the National Science Foundation (EAR-936061). This is contribution no. 1389 of the flfred Wegener Institute, Bremerhaven and Potsdan.

\section{REFERENCES}

Baikal Drilling Project BDP-96 Mexbers, 1997, Continuous paleoclimate record recovered for the last 5 million years: Eos, y. 78, 597-601.

BDP-93 Baikal Drillning Project Menbers, 1997, Preliminary results of the first drilling on Lake Baikal, Buguldeika site, southeastem Siberia: Quaternary Intemational, v. 37, p. 3-17. BISCAYF, P.E., 1964, Distinction between knolinite and chlorite in recent sediments by X-ray diffraction: American Mineralogist, v. 49, p. 1281-1289.

BisCAYE, P.E., 1965, Mineralogy and sedimentation of recent deep-sea clay in the Atlantic 
ocean and adjacent seas and oceans: Geological Society of America, Bulletin, v. 76, p. 803832

CARTER, S. J, ak: COLman, S.M., 1994, Biogenic silica in Lake Baikal sediments: results from 1990-1992 American cores: Journal of Great Lakes Research, v. 20, p. 751-760.

Chamlex, H., 1989, Clay Sedimentology: Berlin, Springer-Verlag, 623 p.

Colman, S.M., Carter, S.J., Hattos, J., and Haskell, B.J., 1994, Cores collected in Lake

Baikal, Siberia, by the U.S. Geological Survey, 1990 to 1992: visual descriptions, photographs, X-radiographs, bulk-density measurements, and grain-size analyses: U.S. Geological Survey, Open-File Report 94-445.

Colman, S., Jones, G.A., Rubin, M., Kng, J.W., Peck, J.A., and Orem, W.H., 1996, AMS radiocarbon analyses from Lake Baikal. Siberia: challenges of dating sediments from a large, oligotrophic lake: Quatemary Science Reviews (Quaternary Geochronology), v. 15, p. 669684.

Colman, S.M., Peck, J.A., Hatton, J., Karabanov, E. And Kng, J.W., in press, Biogenic silica records the BDP-93 drill site and adjacent areas of the Selenga Delta, Lake Baikal, Siberia: Journal of Paleolimnology.

Colman, S.M. Peck, J.A. Karabanov, E.B., Carter, S.J., Bradbitry, J.P., King, J.W and WiLLIass, D.F, 1995, Continental climate response to orbital forcing from biogenic silica records in Lake Baikal: Nature, v. 378, p. 769-771.

Deike, R., Webster, D., nd Callender, E,, 1993, Sedimentary changes and authigenic mineralogy determined from site 307 cores, Academician Ridge, Lake Baikal, Siberia: Russian Geology and Geophysics, v. 34, p. 136-147.

Egerd, D.D., Velde, B., AND MCCormick, T., 1993, Synthesis of illite-smectite from smectite at earth surface temperatures and high pH: Clay Minerals, v. 28, p. 49-60.

Ehrmann, W.U., Meldes, M., Kuhs, G., and Grobe, H., 1992, Significance of clay mineral assemblages in the Antarctic Ocean: Marine Geology, v. 107, p. 249-273.

GIBBs, R.J., 1977, Clay mineral segregation in the marine environment: Journal of Sedimentary Petrology, v. 47, p. 237-243.

Gingele, F., 1996, Holocene climatic optimum in sonthwest Africa-evidence from the marine clay mineral record: Palaeogeography, Palaeoclimatology, Palaeoecology, v. 122, p. 77-87

GrifFr, J.J., WINDOM, H., AND Goldberg. E.D., 1968, The distribution of clay minerals in the World Ocean: Deep-Sea Research, v. 15, p. 433-459.

Hayashida, A., AND YokoYama, T., 1994, Preliminary report on paleomagnetic study of the sediments from Baikal Drilling Project Hole 1: IPPCCE Newsletter, v. 8, p. 30-33

HaYaSHIDA, A., AND YOKOYAMa, T., 1995, Magnetic measurements of the sediments from Baikal Drilling Project Hole 93-2: IPPCCE Newsletter, v. 9, p. 15-17.

Johnson, T.C., 1996, Sedimentary processes and signals of past climatic change in the large lakes of the East African Rift Valley, in Johnson, T.C., and Odada, E.O., eds., The Lim nology, Climatology and Paleoclimatology of the East African Lakes: Amsterdam, Gordon \& Breach, p. 367-412.

JOH:SON, T.C., AND N'GANGA, P., 1990, Reflections on a rift lake, in Katz, B.J., ed., Lacustrine Basin Exploration-Case Studies and Modern Analogs: American Association of Petroleum Geologists, Memoir 50, p. 113-136.

KalindeKafe, L.S.N., Dolozi, M.B., And Yuretich, R., 1996, Distribution and origin of clay minerals in the sediments of Lake Malawi, in Johnson, T.C., and Odada, E.O., eds., The Limnology, Climatology and Paleoclimatology of the East African Lakes: Amsterdam, Gordon \& Breach, p. 443-460.

Kenison Falkner, K., Measures, C.I., Herberl.in, S.E., and Ediond, J.M., 1991, The major and minor element geochemistry of Lake Baikal: Limnology and Oceanography, v. 36, p 413-423.
KHRENov, P.A., 1983, Geological map of the Baikal region, 1:1,000,000: USSR Academy of Sciences, Siberian Division, Institute of the Earth's Crust, Irkutsk.

KozHov, M., 1963, Lake Baikal and its Life: Monographiae Biologicae, Vol. XI: The Hague, Dr. W. Junk, 344 p.

Kukla, G., Heller, F., Lu, X.M., XU, T.C., Luv, T.S., AND AN, Z.S., 1988, Pleistocene climates in China dated by magnetic susceptibility: Geology, v. 16, p. $811-814$.

Kuzaln, M.I., Williams, D.F., Logachev, N.A., Colman, S., Khakaev, B.N., Kawa, T., Hearn, P., Horie, S., Pevzner, L.A., Bukharov, A.A., and Fialkov, V.A., 1993. The Baikal driling program: scientific objectives and recent results: Russian Geology and Geophysics, v. 34, p. 3-11.

Melles, M., Grobe, H., ałd Husberten, H.W., 1995a, Mineral composition of the clay fraction in the $100 \mathrm{~m}$ core BDP-93-2 from Lake Baikal-preliminary results: IPPCCE Newsletter No. 9 , p. $17-22$

Melles, M., Kuhy;, G., Fütterer, D.K., And Meischner, D., 1995b, Processes of modern sedimentation in the southern Weddell Sea, Antarctica - evidence from surface sediments: Polarforschung, v. 64(2), p. 45-74

MeNkivg, K. M, 1997. Climatic sionals in clay mineralogy and grain-size variations in Owens Lake core OL-92, southeast California, in Smith, G.L., and Bischoff, J.L., eds., An 800,000 Year Paleoclimatic Record from Core OL-92, Owens Lake, Southeast California: Geological Society of America, Special Paper 317, p. 25-36.

NowaCZYK, N.R., 1995, Magnetostratigraphy of Lake Baikal sediments-basic results on core BDP-93-2: IPPCCE Newsletter v. 9, p. 8-15.

Peck, J.A., King, J.W., Colman, S.M., And Kravohinsky, V.A., 1994, A rock-magnetic record from Lake Baikal, Siberia: evidence for Late Quatemary climate change: Earth and Planetary Science Letters, v. 122, p. 221-238.

Petschik, R., Kuhs, G., and Gingele, F., 1996. Clay mineral in surface sediments of the South Atlantic: sources, transport and relation to oceanography: Marine Geology, v. 130, p. 203 229.

RaYmo, M.E., and RudDMAN, W.F., 1992, Tectonic forcing of late Cenozoic climate: Nature v. 359 , p. $117-122$

REYsolds, R C, 1980, Interstatified clay minerals, in Brindley, G.W. and Brown, G., eds. Crystal Structures of Clay Minerals and Their X-ray Identification: Mineralogical Society Monograph 5, p. 249-303

Sarata, A.B., AæD Yuretich, R.F.,1995, Preliminary results of clay mineralogy analysis of Baikal Drilling Project core BDP-93-2, Buguldeika Saddle. Lake Baikal, Siberia (abstract): Geological Society of America, Abstracts with Programs, v. 27, no. 6, p. A-132.

Scholz, C.A., Klitgord, K.D., Hutchinson, D.R., Tex Brisk, U.S., Zonenshain, L.P., GolmshroK, A.Y., AND Moore, T.C., 1993, Results of 1992 seismic reflection experiment in Lake Baikal: Eos, v. 74, p. $465-469$

Stoperes, P aNd Hecky, RE 1978, Late Pleistocene-Holocene evolution of the Kivu-Tanganyika Basin, in Matter, A., and Tucker, M.E., eds., Modern and Ancient Lake Sediments: International Association of Sedimentologists, Special Publication 2, p. 43-55.

VoTnSHEv, K.K., 1965, Hydrochemical characteristics in depth zones of Lake Baikal (in Rus sian), in Galazii, G., ed., Limnological Investigations of Baikal and Neighboring Mongolian Lakes: Moscow, Akademiia Nauk SSSR, p. 71-113

WINDOM, H.L., 1976, Lithogenous material in marine sediments, in Riley, J.P., and Chester R., eds., Chemical Oceanography, v. 5: New York, Academic Press, p. 103-135.

Zhно, X., 1992, The Paleoclimate of China: Beijing, Geological Publishing House, 132 p.

Received 28 January 1998; accepted 10 August 1998. 